\title{
Analysis Of Protein Levels With Giving Kelor Leaf Extract (Moringa Oleifera) On Soy Milk
}

\author{
Fajar Nur Atmaja, Byba Melda \\ Suhita, Nurwijayanti \\ Magister of Public Health Program of \\ Institut Ilmu Kesehatan STRADA \\ Indonesia \\ Email: \\ fajard3kep.ssbn@gmail.com
}

Received : October 12, 2019

Accepted : February 13, 2020

Published : May 15, 2020

\begin{abstract}
Soy milk is a beverage product that is currently being favored by the people of Indonesia, to increase the protein content in soy milk needs to be substituted for other ingredients using Moringa Oleifera leaf extract. The purpose of this study was to analyze the organoleptic acceptability of soy milk by giving Moringa Oleifera leaf extract.

This research is quantitative research with experimental research design using the True Experiment research method. This research was conducted in December 2018 until February 2019 at the Food Quality and Safety Testing Laboratory of the Agricultural Product Technology Department of the Faculty of Agriculture, University of Brawijaya Malang to test the protein content while the Organoleptic Test was carried out at STIKeS Satria Bhakti Nganjuk. The sample size is 20 panelists. The independent variable in this study was Moringa leaf extract while the protein content of soy milk. Data was collected using an organoleptic sensory test assessment table and a protein content test sheet using the Kjeldahl method. Data were analyzed using ANNOVA test with the results of $\mathrm{H} 0$ rejected and $\mathrm{H} 1$ accepted with a significant value $<0.05$

The results of ANOVA analysis get $F$ count value of 105,405 and $\mathrm{F}$ table for testing 20 samples to get $\mathrm{F}$ table 4.35 . So that it can be concluded that the addition of Moringa leaf extract $0 \%$ to $10 \%$ Significant and simultaneous organoleptic.

Addition of Moringa Oleifera leaf extract to soy milk affected organoleptic acceptability and increased protein content of soy milk in accordance with the percentage of Moringa leaf extract levels added.
\end{abstract}

Keywords: Moringa Leaf Extract, Soy Milk Protein Level, Organoleptic Test, Kjeldahl Method

\section{(c) (†) (?)}

This is an open-acces article distributed under the terms of the Creative Commons Attribution-ShareAlike 4.0 International License. 


\section{INTRODUCTION}

Milk is one food that is very important for meeting the nutritional needs of the community. Milk acts as an important intake for health, intelligence, and growth, especially for children. Public awareness of milk consumption, making milk as an economic commodity that has a very strategic value. Demand for milk is growing very fast, which increased by 14.01\% during the period between 2002 and 2007. However, on the other hand Indonesian milk production only grew by $2 \%$ (Trade Research, 2011).

Indonesian people's per capita milk consumption will continue to be increased because it currently only reaches 11.09 liters per year, still far below the per capita consumption of other ASEAN countries which reaches more than 20 liters per capita per year. The need for raw materials for domestic fresh milk (SSDN) is currently around 3.3 million tons per year with the supply of raw materials for domestic fresh milk 690 thousand tons per year (21 percent). So it still has to import milk by 2.61 million tons per year (79\%). However, recently milk production in Indonesia has increased by an average of $2.67 \%$ annually. Imported milk in the form of skim milk powder, anhydrous milk fat, and butter milk powder from various countries such as Australia, New Zealand, the United States, and the European Union (Ministry of Industry, 2015). This is a problem in fulfilling milk, where if the increase in consumption is not matched by an increase in milk production, it will have an impact on dependency on imported milk, milk prices will soar.

At present, many mothers are reluctant to breastfeed for some reason and then replace breast milk with cow's milk. However, not a few toddlers who are allergic to cow's milk due to the digestive system is not able to digest and absorb lactose (milk fat) properly, causing symptoms such as nausea, vomiting, diarrhea, and other symptoms of abdominal pain. This condition is termed Lactose Intolerance, which is caused by the limitation of lactase enzymes in the body which functions to break lactose into glucose and galactose (monosaccharides) to make digestibility easier for the intestine (Salim, 2012). The incidence of cow's milk allergy is around 2-7.5\% and an allergic reaction to cow's milk is still possible in $0.5 \%$ of infants who are exclusively breastfed. Most allergic reactions of cow's milk are mediated by $\operatorname{IgE}$ with an incidence of $1.5 \%$, while the rest are non-IgE types. The symptoms that arise are mostly mild to moderate clinical symptoms, only a few (0.1-1\%) have severe clinical manifestations (Sumadiono et all, 2014). Soy milk does not have lactose milk so it is very good for children or adults who are allergic to cow's milk (Salim, 2012).

The quality of soy milk protein is actually almost the same as the quality of cow's milk protein. The quality of this protein is expressed in the Protein Eficiency Ratio (PER). PER soybean milk was 2.3 while cow milk was 2.5. PER 2.3 means that every gram of protein eaten will result in weight gain of 2.3 grams. Thus the higher the PER value the better the quality of the protein (Bekti, 2014). So that cow's milk has better protein quality than soy milk because the absorption process of cow's milk nutrition is much easier than the absorption of vegetable milk nutrition (Yusdita, 2015).

Moringa leaves have a high vegetable protein content, which is $27 \%$ (Pandey, et al., 2012). Qoniah research (2014) which examined the protein content test on biscuits with the addition of moringa leaf flour showed that the highest protein content was obtained in the administration of $30 \%$ Moringa leaf flour (30 grams). While Zakaria's research (2016) which examined the effect of adding Moringa leaf flour to the acceptability and protein content of wet noodles showed that giving Moringa leaf flour 2\% can increase the protein level of wet noodles to 14.84 gram / 100 gram, and giving 4\% leaf flour Moringa can increase protein levels of wet noodles to 14.98 grams / 100 grams. Research conducted by Priyanto \& Nisa (2016) that examined the formulation of Moringa leaves and green grass jelly leaves as composite flour in making instant noodles showed that the administration of Moringa leaf flour was quite significant in increasing the protein content of instant noodles compared to grass jelly leaves.

So to be able to improve the competitiveness of soy milk, it is necessary to improve the quality of the product. One such effort is to increase protein levels in soy milk. To increase the protein content in soy milk, it is necessary to substitute other ingredients. One natural ingredient that can be used as a substitute is Moringa leaf extract. With the addition of Moringa leaf extract in soy milk is expected to increase protein levels in soy milk. So from some of the problems that exist in soy milk and some studies conducted to increase protein levels of food ingredients, the authors are interested in conducting research with the title "Analysis of protein content by giving Moringa leaf extract in soy milk" 


\section{METHODS}

The experimental method that I use is the true experimental method. The object of this research is soy milk with the addition of Moringa leaf extract $0 \%, 5 \%, 7.5 \%$ and $10 \%$. The sampling technique in this study uses the Nonprobability technique that is saturated sample or often called total sampling

The independent variable in this study is Moringa leaf extract while the dependent variable in this study is the protein content of soy milk. Using the Kjeldahl method test as an instrument. The Kjeldahl test results are then documented in the check list sheet. Data analysis was performed using the ANOVA Test.

\section{RESULTS}

\section{CHARACTERISTICS OF MATERIALS}

a. Characteristics of soy milk

Soybean used for making soymilk is selected from local soybeans with suitable varieties, namely yellow seed, high protein content and low unpleasant intensity.

b. Characteristics of Moringa Oleifera Leaf Extract

Moringa oleifera leaf extract is made by extracting leaf powder using maceration method until it forms a paste.

c. Sample Characteristics

In this study, using 4 samples where each sample has different characteristics, namely:

1) The first sample (F0) was $320 \mathrm{ml}$ soy milk without the addition of Moringa Oleifera leaf extract.

2) The second sample (F1) is $320 \mathrm{ml}$ soy milk with the addition of Moringa Oleifera leaf extract of 5 grams $(5 \%)$.

3) The third sample (F2) was $320 \mathrm{ml}$ soy milk with the addition of Moringa Oleifera leaf extract of 7.5 grams $(7.5 \%)$.

4) The fourth sample (F3) is $320 \mathrm{ml}$ soy milk with the addition of Moringa Oleifera leaf extract of 10 grams $(10 \%)$.

1. Organoleptic test results on soymilk before being given Moringa Oleifera (0\%) leaf extract, by evaluating the color, aroma, taste, texture with 20 panelists:

a) In sample F0, namely soy milk with the addition of $0 \%$ Moringa leaf extract, the most score is 4 with a percentage of $100 \%$ (20 panelists), so that soy milk is included in the criteria of white color,

b) Taste is one of the assessment indicators that can be felt directly with the taste buds in sample F0, namely soy milk without the addition of moringa leaf extract $(0 \%)$ the most score is 2 with a percentage of $85 \%$ (17 panelists) with the criteria for the taste of soy milk being rather savory, then for The second highest score is 1 with a percentage of $10 \%$ ( 2 panelists) with the criteria of taste not tasty. And in the last place was a score of 3 with a percentage of 5\% (1 panelist) with the criteria for the taste of savory soy milk. It can be concluded that the organoleptic test of taste assessment on F0 samples by panelists, the majority of panelists (85\%) stated that the taste of soy milk was rather savory.

c) Texture is the physical appearance of a product, in sample F0, namely soy milk with the addition of $0 \%$ Moringa leaf extract, the most score is 4 with a percentage of $100 \%$ (20 panelists), so that soy milk is included in the very dilute criteria.

d) For the aroma of soy milk in sample F0, namely soy milk with the addition of $0 \%$ Moringa leaf extract, the highest score is 4 with a percentage of $100 \%$ (20 panelists), so that soy milk is included in the highly flavored criteria of soy milk.

e) For the acceptability of soy milk in sample F0, namely soy milk with the addition of $0 \%$ Moringa leaf extract, the highest score is 3 with a percentage of $85 \%$ (17 panelists) with acceptance criteria like. And the rest with a score of 2 with a percentage of $15 \%$ ( 3 panelists) with acceptance criteria does not like. out of 20 panelists who said they didn't like 3 people and 17 people said they liked it.

2. Organoleptic test results on soy milk after Moringa Oleifera leaf extract $(0 \%, 5 \%, 7.5 \%, 10 \%)$, by evaluating the color, aroma, taste, texture with 20 panelists were as follows: following: 
From the four samples above it can be concluded that the one who has the highest preference level is the second sample (f1), namely soy milk with the addition of Moringa Oleifera leaf extract of 5 grams (5\%), the highest score is 4 with a percentage of 100\% (20 panelist) with acceptance criteria really like. While the one with the lowest preference level was the fourth sample (f4), namely soy milk with the addition of Moringa Oleifera leaf extract of 10 grams (10\%) the highest score was 1 with a percentage of $100 \%$ (20 panelists) soy milk with criteria power is very dislike.

3. ANNOVA Test Analysis Results

Table 4.5 Test analysis of ANOVA in soy milk with the addition of Moringa Oleifera leaf extract $(0 \%, 5 \%, 7.5 \%, 10 \%)$

\begin{tabular}{|l|l|l|l|l|l|}
\multicolumn{7}{|c|}{ ANOVA } & & & \\
\hline \hline \multicolumn{1}{|c|}{ Organoleptik } & & & & & Sig. \\
\hline & Sum of Squares & df & Mean Square & F & \\
\hline Between Groups & 186.400 & 3 & 62.133 & 105.405 & .000 \\
Within Groups & 44.800 & 76 & .589 & & \\
Total & 231.200 & 79 & & & \\
\hline
\end{tabular}

Based on table 4.5 ANOVA analysis results get the calculated $\mathrm{F}$ value of 105.405 and the $\mathrm{F}$ table for testing 20 samples get the $\mathrm{F}$ table value of 4.35 . So it can be concluded from the addition of $0 \%$ to $10 \%$ Moringa leaf extract Significant and simultaneous organoleptically.

Based on table 4.5 obtained results $(\rho=0,000<\alpha=0.05)$ which means Ho is rejected and H1 is accepted which can be interpreted that there is an effect of Moringa leaf extract is effective in increasing organoleptic acceptance in soy milk.

\section{DISCUSSION}

Milk is one food that is very important for meeting the nutritional needs of the community. Milk acts as an important intake for health, intelligence, and growth, especially for children. Public awareness of milk consumption, making milk as an economic commodity that has a very strategic value. Demand for milk is growing very fast, which increased by $14.01 \%$ during the period between 2002 and 2007. However, on the other hand Indonesian milk production only grew by $2 \%$. The quality of soy milk protein is actually almost the same as the quality of cow's milk protein. The quality of this protein is expressed in the Protein Eficiency Ratio (PER). PER soybean milk was 2.3 while cow milk was 2.5. PER 2.3 means that every gram of protein eaten will result in weight gain of 2.3 grams. Thus the higher the PER value the better the quality of the protein (Bekti, 2014). So that cow's milk has better protein quality than soy milk because the absorption process of cow's milk nutrition is much easier than the absorption of vegetable milk nutrition. So to be able to improve the competitiveness of soy milk, it is necessary to improve the quality of the product. One such effort is to increase protein levels in soy milk. To increase the protein content in soy milk, it is necessary to substitute other ingredients. One natural ingredient that can be used as a substitute is Moringa leaf extract. With the addition of Moringa leaf extract in soy milk is expected to increase protein levels in soy milk. So from some of the problems that exist in soy milk and some studies conducted to increase protein levels of food ingredients, the purpose of this study is to analyze the organoleptic acceptability of soy milk by giving Moringa Oleifera leaf extract.

Soy milk is a beverage product that is currently starting to be favored by the Indonesian people, besides having a delicious taste, soy milk also has a high nutritional content including: protein, fat, carbohydrates, calcium, phosphorus, iron, provitamin A, Vitamin B complex (except B12), and water. Soybean used for making soymilk is selected from the appropriate varieties, namely yellow seed, high protein content and low intensity of unpleasant odor. While Moringa oleifera (Moringa oleifera) is one type of tropical plant that is easy to grow in tropical regions such as Indonesia. Moringa plants are shrubs with a height of 7-11 meters and thrive from the lowlands to an altitude of $700 \mathrm{~m}$ above sea level. Moringa can grow in tropical and subtropical regions on all soil types and is resistant to drought with tolerance to drought for up to 6 months This research is a quantitative study with an experimental research design using the True Experiment 
research method. This research was conducted in December 2018 to February 2019 in the Laboratory of Food Quality and Safety Testing of the Department of Agricultural Product Technology, Faculty of Agricultural Technology, Universitas Brawijaya Malang to test protein levels while the Organoleptic Test was conducted at STIKeS Satria Bhakti Nganjuk. The sample size is 20 panelists. The independent variable in this study was Moringa leaf extract while the protein content of soy milk. Data were collected using an organoleptic sensory test assessment table and a protein content test result sheet using the Kjeldahl method. Data were analyzed using ANNOVA test with the results of H0 rejected and $\mathrm{H} 1$ accepted with a significant value $<0.05$

Taste is important in determining the acceptability or rejection of a food item by panelists. In this research, taste is one of the indicators tested to get the best results that have been tested by panelists. Organoleptic test results on taste have the aim to determine the level of response from the panelists regarding his preference for soy milk produced in each treatment. Food taste is an important aspect of determining the quality of food ingredients. Foods that taste good are preferred by consumers. Organoleptic test results with flavor indicators in all four samples (F0, F1, F2, F3) that have the highest taste are F3 samples, namely soy milk with the addition of Moringa leaf extract (10\%) with the highest score is 4 with a percentage of $90 \%$ (18 panelist) and who has the lowest level of savory taste is the F0 sample that is soy milk without the addition of Moringa leaf extract ( $0 \%)$ the highest score is 2 with a percentage of $85 \%$ (17 panelists). The addition of Moringa Oleifera leaf extract to soy milk can affect organoleptic reception and increase protein content of soy milk according to the percentage of added Moringa leaf extract. Where soybean milk samples with the addition of 5\% Moringa leaf extract has a very good acceptance in the Organoleptic test and has a higher Protein content than soy milk without the addition of Moringa leaf extract so it needs to be socialized to the public because it is useful as a functional food. The process of making Moringa leaf extract must really pay attention to the level of hieginitas to avoid bacterial and fungal contamination. The higher the level of moringa leaf powder mesh used the easier it is to do the extraction process.

Color is one of the important aspects in terms of consumer acceptance of a food product. Color in food can be a measure of quality, color can also be used as an indicator of freshness or maturity. Panelist assessment results showed the highest green color was F3 sample, namely soy milk with the addition of Moringa leaf extract 10\%, the highest score was 4 with a percentage of $90 \%$ (18 panelists), while the one with the lowest green level was F0 sample, namely soy milk with Moringa leaf extract addition is $0 \%$, the highest score is 4 with a percentage of $100 \%$ ( 20 panelists).

The aroma is a reaction from food that will affect consumers before consumers enjoy food, consumers can smell the food. (Margaretha, 2012), the substitution of the addition of Moringa leaf extract in soymilk made a change in the aroma of soymilk as indicated by the results of the Organoleptic test, from the results of the panelist assessment which had the lowest aroma of soymilk, namely F3 sample, namely soy milk with the addition of extract Moringa leaves $10 \%$, the highest score is 1 with a percentage of $90 \%$ (18 panelists).

Organoleptic assessment of the acceptability of soy milk with the addition of moringa leaf extract showed that the highest preference level was the second sample (f1), namely soy milk with the addition of Moringa Oleifera leaf extract by 5 grams (5\%), while the has the lowest preference level of acceptance is the fourth sample (f4)), namely soy milk with the addition of Moringa Oleifera leaf extract of 10 grams $(10 \%)$.

ANOVA analysis results obtained a calculated $F$ value of 105.405 and $F$ table for testing 20 samples obtained a $\mathrm{F}$ table value of 4.35 . So it can be concluded Addition of $0 \%$ to $10 \%$ Moringa leaf extract Significant and simultaneous organ Addition of Moringa Oleifera extract to soy milk affects organoleptic acceptability and increases protein content of soy milk according to the percentage of Moringa leaf extract added. .

The higher the percentage of moringa leaf extract added to soymilk makes the receiving power of soymilk lower, because the higher the content of the moringa leaf extract substituted in soymilk makes the aroma of moringa (langu) more pronounced and removes the aroma of soymilk. The higher percentage of the addition of Moringa leaf extract to soy milk also makes the texture of soy milk thicker so that the panelist ratings are low. 


\section{CONCLUSION}

Based on the results of research and discussion, the following conclusions can be drawn:

1. Soymilk which has not been added by Moringa leaf extract has not changed organoleptically and there has not been an increase in protein content.

2. In soy milk that has been added Moringa leaf extract occurs organoleptic changes and increased levels of protein in accordance with the percentage of Moringa leaf extract levels added.

3. ANNOVA test results indicate the addition of Moringa leaf extract to soy milk affects the organoleptic acceptability of soy milk.

4. Protein content test results using the Kjeldahl Test method show the addition of Moringa leaf extract to soy milk affects the increase in protein levels in soy milk

\section{REFERENCES}

Alimul Hidayat A.A., (2010), Metode Penelitian Kesehatan Paradigma Kuantitatif, Health Book, Jakarta

Andarwulan, N., Kusnandar , F., dan Herawati, 2011, Analisis pangan, Dian Rakyat, Jakarta

Bekti, 2014, Uji Komposisi dan Konsentrasi Starter Bakteri Lactobacillus acidophilus Bifidobacterium bifidum Terhadap Kualitas Susu Kedelai Fermentasi (Yoghurt), Ethesis UIN, Malang

Burssens, S., I. Pertry, D.D. Ngudi, Y. Kuo, M.V. Montagu and F. Lambein. 2011. Soya, Human Nutrition and Health. pp.157-180. Hany A. El-Shemy (ed.). In Soybean and Nutrition. InTech. Croatia.

Kementrian Perindustrian. (2015). Bahan Baku Susu Didominasi Produk Impo. http://www.kemenperin.go.id/artikel/8883/Bahan-Baku-Susu-Didominsi-ProsukInpor. Diakses tanggal 9 februari 2017.

Das, AK., Rajkumar, V, Verma, A. K., \& Swarup, D. (2012), Moringa Oleifera; eaves extract: A natural antioxidant for retarding lipid peroxidation in cooked goat meat patties, International Journal of Fppd Science and Technology, 47

Krissetiana, 2015, Uji Organoleptik Bahan Pangan, PT. Citra Aji Parama, Yogyakarta

Lyrawati, D., Indra, M.R., R, Fitria N, 2013. Ekstra Metanol Daun Kelor Mempengaruhi Ekspresi p53 Mukosa Kolon Tikus yang Diinduksi DMBA, Jurnal Kedokteran Brawijaya, Vol.27, No.24

Mendieta-Araica B, Sporndly E, ReyesSanchez N, Salmeron-Miranda F, Halling M (2013). Biomass production and chemical composition of Moringa oleifera under different planting densities and levels of nitrogen fertilization. Agroforest. Syst. 87:81-92.

Misra, S., \& Misra, M. K. (2014). Nutritional evaluation of some leafy vegetable used by the tribal and rural people of south Ordisha, India, Journal of Natural Product and Plant Resources, 4, 23-28.

Miftah, 2011, Pengembangan Susu Segar Dalam Negeri Untuk Pemenuhan Kebutuhan Susu Nasional, Buletin Ilmiah Litbang Perdagangan, Jakarta

Mahmood KT. Tahira Mugal, Ikram UI Haq, 2011, Moringa oleifera, a natural gift-A review. Journal of Pharmaceutical Sciences and Research 2 (11): 775-781

Nursalam, (2014), Manajemen Keperawatan: Aplikasi Dalam Praktik Keperawatan Profesional, Salemba Medika, Jakarta

Notoatmojo, 2010, Metodologi Penelitian Kesehatan, PT. Rineka Cipta, Jakarta

Pandey. Et.al. 2012, Antibacterial and antioxidant activity of diffetent extract moringa oliefera leaves an in vitro study. Internasional Journal of Pharmaceutical sciences review and research.

Pahmi. 2017, Protein Dalam Biomenik, Pustaka Panasea, Yogyakarta 
Priyanto, AD \& Nisa, 2016, Formulasi daur kelor dan ampas daun cincau hijau sebagai tepung komposit pada pembuatan mie instan, Jurnal Teknologi Pertanian, Vol 17 (1), Hal: 2936

Poedjiadi, A., dan Supriyadi, F.M.T., 2012, Dasar - Dasar Biokimia Edisi Revisi. Penerbit Universitas Indonesia (UI-Press), Jakarta.

Qoniah. (2014), Uji kadar protein dan uji organoleptic biscuit dengan rasio tepung terigu dan tepung daun kelor (Moringa Oleifera) yang ditambahkan sari buah nanas, Tesis Universitas Muhammadiyah Surakarta

Salim, 2012, Kiat Cerdas Wirausaha Aneka Olahan Kedelai, Lily Publisher; Yogyakarta

Sugiyono, 2011, Metode Penelitian Kuantitatif Kualitatif dan R\&D, Alfabeta; Bandung

Sumadiono et all, 2014, Diagnosis Dan Tata Laksana Alergi Susu Sapi, Edisi Kedua, Badan Penerbit Ikatan Dokter anak Indonesia, Jakarta

Tilong AD, 2010, Ternyata Kelor Penakluk Diabetes. DIVIA Press, Yogyakarta

Thenawidjaja et all, 2017, Protein Sereal Biokima Mudah dan Menggugah, Grasindo, Jakarta Wirjatmadi, 2016, Pengantar Gizi Masyarakat, Kencana, Jakarta

Yameogo, W. C., Bengaly, D. M., Savadogo, A., Nikiema, P. A., Traore, S. A. 2011. Determination of Chemical Composit and Nutritional values of Moringa Oleifera Leaves. Pakistan Journal of Nutrition 10 Vol (3): 264-268.

Yenrina, 2015, Metode Analisis Bahan Pangan dan Komponen Bioaktif, Andalas University Press, Padang

Zakaria, 2016, Pengaruh penambahan tepung daun kelor terhadap daya terima dan kadar protein mie basah, Media Gizi Pangan, Vol, 21 (1): hal, 73-79 